\title{
Detection of leptospires from infected urine and tissue samples in vitro by modified Fontana silver stain
}

\author{
Detecção de leptospiras na urina e nos tecidos infectados in vitro por \\ impregnação com prata Fontana modificada
}

\author{
Islay Rodríguez; ; Iuley Rodríguez²; Carmen Fernández³; José E. Rodríguez; ; Jorge Cantillo ${ }^{5}$
}

\begin{abstract}
Introduction: The microbiological diagnosis of leptospirosis comprises bacteriological and serological methods. The former ones allow the direct detection of leptospires and are considered presumptive with the exception of culture. Therefore, they constitute invaluable tools for rapid diagnosis, mainly in samples from deceased subjects. Objective: To evaluate a modified Fontana silver staining method in experimentally infected samples. Material and methods: Human and animal (hamster) urine samples were experimentally infected with different strains of Leptospira interrogans sensu lato. Liquid culture medium, leptospira cultures, experimentally infected and non-infected human urine samples, clarified and non-clarified imprints, and clarified and non-clarified suspension smears from tissues of experimentally infected and non-infected hamsters were applied for the ass essment of silver staining. The analytical sensitivity of the assay was compared with dark field microscopy and culture. Other bacterial and fungi species were also used. Results: The modified Fontana silver staining allowed the accurate observation of the well-defined leptospire helical structure. On leptospire cultures from infected human samples, we could observe until $(1-10) \times 10^{3}$ leptospires $/ \mathrm{ml}$, higher sensitivity in comparison with direct dark field microscopy and lower in comparison with culture. The best results in tissues were obtained on clarified imprints and non-clarified suspension smears. Morphological and stainable structures compatible with leptospires were not observed in the samples without them. Conclusion: This procedure allowed differentiating the characteristic morphology of leptospires. As its application suggests, it consists of a simple and easily conducted procedure with stable reagents.
\end{abstract}

Key words: leptospira; silver staining; leptospirosis; diagnosis.

\section{INTRODUCTION}

Leptospirosis is a worldwide zoonosis, which bears considerable medical and economic relevance. It is caused by spirochetes belonging to the Leptospira interrogans sensu lato (sl) (pathogenic group $)^{(1,5)}$. It has been acknowledged as a neglected and likewise emerging infectious disease in the last 20 years, hence its recent major outbreaks in different countries ${ }^{(1,9,12)}$.

Leptospires are usually present in the blood during the first week of infection and are excreted in the urine from the second week onwards up to a month or even more. Major causes of death include renal failure, cardiopulmonary failure, and widespread hemorrhage ${ }^{(1,5,19)}$.

The direct demonstration of its causative agent is an invaluable tool for rapid diagnosis. However, current bacteriological methods for the detection of leptospires in clinical specimens such as blood, cerebrospinal fluid, urine and post mortem tissue have some disadvantages: leptospires are poorly stained with conventional methods; dark field microscopy is relatively unreliable due to possible errors caused by leptospira-like artifacts; culturing is time-consuming to be of value for a rapid diagnosis ${ }^{(1,5,17,19)}$.

Leptospires can be stained in formalin fixed tissue sections by Dobell method for blocks, or Warthin-Starry, Faine, or Dieterle methods for cutting sections from paraffin blocks. The use of paraffin blocks is a tedious and time-consuming procedure ${ }^{(5,19)}$.

This paper reports the evaluation of a modified Fontana silver staining method in the direct detection of leptospires from urine samples mixed with leptospire cultures and non-paraffin embedded experimentally infected animal tissue. This enabled a quantitative approach to the detection of leptospires in the specimens.

First submission on $06 / 06 / 12$; last submission on $28 / 09 / 12$; accepted for publication on $04 / 10 / 12$; published on 20/02/13

1. Doctor in Health Sciences; researcher and professor of Microbiology at the Tropical Medicine Institute Pedro Kourí (IPK)

2. Microbiologist; laboratory specialist at IPK.

3. Doctor in Health Sciences; researcher and professor of Microbiology at IPK.

4. Senior Microbiology technician at IPK.

5. Veterinary Medical doctor; head of the Department of Experimental Animals at IPK. 


\section{MATERIAL AND METHODS}

\section{Strains}

Leptospiral and other bacterial or fungal strains were used in this study. Details are described in Table 1.

Pure cultures of reference leptospiral strains with 7-10 days of growth at $28-30^{\circ} \mathrm{C}$ were applied. Leptospires were inoculated into Ellinghausen-McCullough-Johnson-Harris (EMJH) medium and enriched with $10 \%$ salts, albumin, vitamins, antimicrobial agents and Tween (SAVAT) supplement.

\section{Specimens of leptospiral culture and experimentally infected urine}

Ten different cultures of pathogenic leptospira were diluted with equal quantities of EMJH-SAVAT medium. In order to determine the concentration of leptospires in each sample, the optical density (OD) to $\lambda=420 \mathrm{~nm}$ was measured. Subsequently, decimal and serial dilutions were conducted (10-1 to 10-8) for each one.

Urine specimens from 10 healthy persons were taken from each subject. These samples were divided in two fractions, one of them was alkalinized ( $\mathrm{pH} 7-8)$ with $\mathrm{NaOH} 4 \mathrm{~N}$ and the other one was kept at its natural state ( $\mathrm{pH} 5-6.5)$. All these fractions were mixed with 10 different cultures of pathogenic leptospire in equal quantity. The concentration of leptospires was determined and decimal and serial dilutions were performed as described above.

Non-inoculated EMJH-SAVAT medium and urine (alkalinized and natural) diluted 1:2 with medium were used as controls.

Three aliquots from each dilution and control were observed by dark field microscopy, inoculated in EMJH-SAVAT medium, incubated at $28-30^{\circ} \mathrm{C}$ and periodically checked macro and microscopically for 40 days.

A loopful of each leptospira culture dilutions or leptospira urine mix dilutions was placed at one end of a clean slide and a film was drawn in one stroke. The smear was air dried and labeled carefully in order to avoid the risk of infection through direct contact of fingers with the smear surface.

The remaining volumes were centrifuged for 10 minutes at $6,500 \mathrm{rpm}$, the supernatants were centrifuged for 30 minutes at $12,000 \mathrm{rpm}$, and a smear from each final sediment was made on the slide.

\section{Experimental infection of animal tissues with leptospires}

Ten golden male Syrian hamsters (Mesocricetus aureatus) weighing 10-30 g were used based on the three Rs of Russell and Burch (replacement, reduction and refinement) ${ }^{(2)}$. Eight animals were intraperitoneally inoculated with $1 \mathrm{ml}$ of $10^{8}$ cells $/ \mathrm{ml}$ culture of Copenhageni M20, Tropica 299, Canicola Hond Utrecht IV and

TABLE 1 - Classification of leptospiral and other fungi and bacterial strains used in this study

\begin{tabular}{|c|c|c|}
\hline Leptospiral strains & Serovar & Strain \\
\hline \multirow[t]{10}{*}{ L. interrogans sl } & Tropica & 299 \\
\hline & Copenhageni & M20 \\
\hline & Shermani & $1342 \mathrm{k}$ \\
\hline & Canicola & Hond Utrecht IV \\
\hline & Ballum & Mus 127 \\
\hline & Hardjo & Hardjoprajitno \\
\hline & Pyrogenes & Salinem \\
\hline & Bratislava & Jez Bratislava \\
\hline & Tarassovi & Perepelitsin \\
\hline & Bataviae & Swart \\
\hline L. biflexa sl & Patoc & Patoc I \\
\hline Other bacteria and fungi & & Strain \\
\hline Escherichia coli & & Field strain* \\
\hline Klebsiella sp. & & Field strain* \\
\hline Proteus sp. & & Field strain* \\
\hline Staphylococcus aureus & & Field strain* \\
\hline Candida albicans & & Field strain* \\
\hline Aspergillus fumigatus & & Field strain* \\
\hline
\end{tabular}

* Isolated from Cuban patients. Provided by national reference laboratories of acute diarrheic diseases, acute respiratory infections and fungi/yeasts from the "Pedro Kouri" Tropical Medicine Institute, Cuba. 
Ballum Mus 127 strains of Leptospira interrogans sl (two animal/ serovar), and the other two were inoculated with non pathogenic leptospira and sterile medium, respectively (controls).

The animals were observed daily in order to detect the deceased ones until day 20. The surviving animals underwent cervical dislocation. Kidneys, liver, spleen, lungs and heart were taken aseptically from all animals.

Imprints of the surface of the suspected tissues were performed on clean slides and air dried. They were clarified by treatment with $10 \%$ acetic acid for 5-10 minutes, rinsed with water and air dried. The specimens were further clarified, when it was necessary, with $0.25 \%$ trypsin in buffer $\mathrm{pH} 7.8$ for 3-5 minutes.

The different tissues were disrupted by use of syringe and collected in tubes with sterile phosphate buffered solution (PBS). The tubes were vortexed and later centrifuged for 10 minutes at 3,000 rpm. Leptospires were identified by dark field microscopy from the supernatant and smears for copies on slides were also performed. Only one copy of each tissue was clarified.

Three aliquots from each supernatant were inoculated into EMJH-SAVAT medium and incubated at $28-30^{\circ} \mathrm{C}$ for 40 days. They were periodically checked by dark field microscopy.

\section{Other microorganisms}

One drop of sterile distilled water and a loopful of each culture were put on clean slides, mixed and different smears were performed.

\section{Staining procedure}

We used the modified procedure reported by Gangadhar and Rajasekhar in $1998^{(6)}$. Briefly, the slides with the smears or imprints were placed vertically in a $100 \mathrm{ml}$ capacity beaker containing the fixing reagent $(1 \mathrm{ml}$ glacial acetic acid $+2 \mathrm{ml}$ formalin $[40 \%$ formaldehyde solution] + $100 \mathrm{ml}$ distilled water) for 2 minutes, then they were removed by forceps, blotted onto tissue paper and dipped in a beaker containing absolute alcohol or methanol for 3 minutes. The under surface of the slides were cleaned with filter paper and the smears were air dried. The slides were then dipped in a $100 \mathrm{ml}$ beaker containing the mordant $(1 \mathrm{~g}$ phenol $+5 \mathrm{~g}$ tannic acid + $100 \mathrm{ml}$ distilled water) pre-heated to $75^{\circ} \mathrm{C}$ in a hot water bath and allowed to react for 1 minute. Afterwards, they were rinsed in distilled water, the under surface wiped and air dried. The slides were dipped in a $100 \mathrm{ml}$ beaker containing the ammoniated silver solution (see preparation) pre-heated to $75^{\circ} \mathrm{C}$ in a hot water bath and allowed to react for 1 minute. The slides were then rinsed with distilled water, the under surface cleaned, air dried and examined under bright field microscope using oil immersion lens.

Preparation of ammoniated silver solution: $100 \mathrm{ml}$ of $0.6 \%$ silver nitrate solution prepared in distilled water was divided into 60 and $40 \mathrm{ml}$ aliquots and transferred to separate glass flasks. To the $60 \mathrm{ml}$ aliquot, a few drops of $10 \%$ ammonia solution was added and shaken to obtain a brown precipitate. This was followed by further addition of 0.5 to $1 \mathrm{ml}$ or more of ammonia solution till all the precipitate was dissolved. Small quantities of silver nitrate solution from the $40 \mathrm{ml}$ aliquot were transferred to the above ammoniated silver nitrate solution till a stable precipitate reappeared. Remaining unused silver nitrate solution from the $40 \mathrm{ml}$ aliquot was discarded.

\section{Statistical analysis}

Data were stored in an Excel spread sheet (Microsoft Office) for analysis. Absolute frequencies and percentages were calculated, and comparison test for proportions was conducted using EPIDAT 3.1 statistical software.

\section{Ethical aspects}

The experiment was performed in accordance with the Ethics Committee of Instituto Pedro Kourí. The human urine samples were collected with the volunteers' previous consent and they were used exclusively in this investigation. Cervical dislocation was used as a physical method of euthanasia for the surviving animals according to the recommendations of Directorate-General of the Environment, Nuclear Safety, and Protection (DGXI) of the European Commission for euthanasia of experimental animals ${ }^{(3)}$. This procedure was conducted by a highly experienced specialist in a rapid and effective way. All procedures were performed in a laminar flow cabinet in a biosafety level II facility.

\section{RESULTS}

By use of modified Fontana silver impregnation, the leptospires were stained brown and appeared as long curved organisms with one or both characteristically hooked extremities against a clear white or pale yellow background. The final helical structure of the organism was clearly visible under oil immersion (Figure).

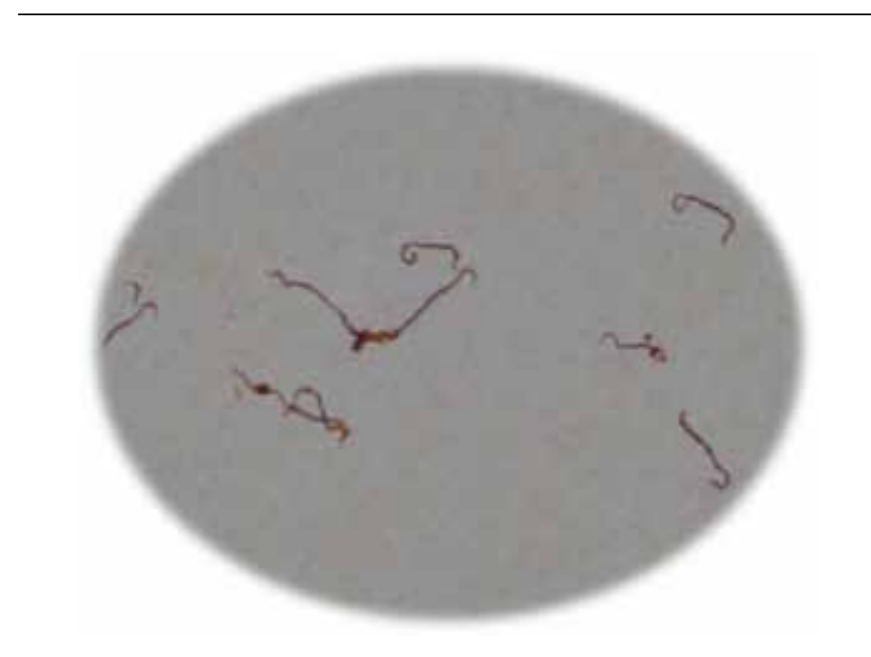

FIGURE - Leptospires from a culture stained by modified Fontana silver technique (3.000×) 
The results of quantitative examination by dark-field microscopy, culture and silver staining of leptospiral cultures and experimentally infected natural or alkaline urine samples are presented in Tables 2, 3 and 4. Leptospires could be identified by silver staining at a density of approximately $10^{3}$ per $\mathrm{ml}$ in sediments from culture and urine samples. Statistical differences $(\phi<0.05)$ were detected among the proportions.

Hamsters infected with Copenhageni or Tropica serovars of Leptospira began to show symptoms of illness between days 3 and 5 , and all died before day 7 . Abundant jaundice, increased organ size and hemorrhages were macroscopic and histopathological changes observed in these animals. In contrast, the animals infected with Ballum or Canicola serovars, similarly to control hamsters, did not show any symptom and they were sacrificed at day 20.

The results of the different methods and variants for the direct demonstration of leptospires in organs of hamsters with leptospirosis are demonstrated in Table 5. The best results were obtained by silver staining from clarified imprints and non-clarified smears of the studied tissues, although there were no statistical differences among the proportions $(p>0.05)$.

When studying the organs of animals infected with Ballum and Canicola serovars, we only detected leptospires by silver staining (modified Fontana) in spleen and lung of one animal infected by Canicola serovar, and we isolated leptospires from kidney of one animal infected by Ballum serovar.

The results of silver staining using clarified imprints and nonclarified smears were compared and the correlation (positive and negative results) was $60 \%(12 / 20)$. These results were also compared with culture, and the correlation was 35\% (7/20) for both.

The specificity of silver staining (modified Fontana) was determined using the negative control specimens (EMJH-SAVAT medium, natural and alkalinized urine and tissue from control animals without leptospires). In all cases leptospires or similar artifacts were not detected.

Silver staining was also applied with other microbial forms (bacteria, yeast and fungi), and all of them were stained distinguishing their different forms.

TABLE 2 - Proportion of positive results and sensitivity of different methods for detection of leptospires from cultures

\begin{tabular}{ccccc}
\hline $\begin{array}{c}\text { Concentration of } \\
\text { leptospires (cells/ml) }\end{array}$ & Dark-field microscopy & Culture & \multicolumn{2}{c}{ Silver staining (modified Fontana) } \\
\cline { 3 - 5 } & & & Smears from cultures & Smears from sediments \\
\hline$(1-10) \times 10^{7}$ & $10 / 10$ & $10 / 10$ & $10 / 10$ & $10 / 10$ \\
$(1-10) \times 10^{6}$ & $10 / 10$ & $10 / 10$ & $10 / 10$ & $10 / 10$ \\
$(1-10) \times 10^{5}$ & $10 / 10$ & $10 / 10$ & $10 / 10$ & $10 / 10$ \\
$(1-10) \times 10^{4}$ & $2 / 10$ & $10 / 10$ & $2 / 10$ & $6 / 10$ \\
$(1-10) \times 10^{3}$ & $0 / 10$ & $10 / 10$ & $0 / 10$ & $0 / 10$ \\
$(1-10) \times 10^{2}$ & $0 / 10$ & $6 / 10$ & $0 / 10$ & $0 / 10$ \\
$(1-10) \times 10$ & $0 / 10$ & $5 / 10$ & $0 / 10$ & $0 / 10$ \\
$(1-10)$ & $0 / 10$ & $5 / 10$ & $0 / 10$ & $(1-10) \times 10^{4}(100 \%)$ \\
\hline \\
Analytical sensitivity & $(1-10) \times 10^{5}(100 \%)$ & $(1-10) \times 10^{2}(60 \%)$ & $(1-10) \times 10^{5}(100 \%)$ & $(1-10) \times 10^{3}(60 \%)$ \\
\hline
\end{tabular}

TABLE 3 - Proportion of positive results and sensitivity of different methods for detection of leptospires from experimentally infected natural urine samples $(\operatorname{acid} \mathrm{pH})$

\begin{tabular}{ccccc}
\hline $\begin{array}{c}\text { Concentration of } \\
\text { leptospires (cells/ml) }\end{array}$ & Dark-field microscopy & Culture & \multicolumn{2}{c}{ Silver staining (modified Fontana) } \\
\cline { 3 - 5 } & & & $\begin{array}{c}\text { Smears from } \\
\text { urine samples }\end{array}$ & Smears from sediments \\
\hline$(1-10) \times 10^{7}$ & $10 / 10$ & $5 / 10$ & $10 / 10$ & $10 / 10$ \\
$(1-10) \times 10^{6}$ & $10 / 10$ & $5 / 10$ & $10 / 10$ & $10 / 10$ \\
$(1-10) \times 10^{5}$ & $9 / 10$ & $3 / 10$ & $10 / 10$ & $10 / 10$ \\
$(1-10) \times 10^{4}$ & $3 / 10$ & $4 / 10$ & $2 / 10$ & $9 / 10$ \\
$(1-10) \times 10^{3}$ & $0 / 10$ & $2 / 10$ & $0 / 10$ & $1 / 10$ \\
$(1-10) \times 10^{2}$ & $0 / 10$ & $1 / 10$ & $0 / 10$ & $1 / 10$ \\
$(1-10) \times 10$ & $0 / 10$ & $2 / 10$ & $0 / 10$ & $1 / 10$ \\
$(1-10)$ & $0 / 10$ & $2 / 10$ & $0 / 10$ & $(1-10) \times 10^{4}(90 \%)$ \\
\hline Analytical sensitivity & $(1-10) \times 10^{5}(90 \%)$ & Non-determined & $(1-10) \times 10^{5}(100 \%)$ & $(1-10) \times 10^{3}(40 \%)$ \\
$($ diagnostic sensitivity) & & & \\
\hline
\end{tabular}


TABLE 4 - Proportion of positive results and sensitivity of different methods for detection of leptospires from experimentally infected alkaline urine samples

\begin{tabular}{|c|c|c|c|c|}
\hline \multirow{2}{*}{$\begin{array}{l}\text { Concentration of } \\
\text { leptospires (cells/ml) }\end{array}$} & \multirow[b]{2}{*}{ Dark-field microscopy } & \multirow[b]{2}{*}{ Culture } & \multicolumn{2}{|c|}{ Silver staining (modified Fontana) } \\
\hline & & & $\begin{array}{l}\text { Smears from } \\
\text { urine samples }\end{array}$ & Smears from sediments \\
\hline$(1-10) \times 10^{7}$ & $10 / 10$ & $5 / 10$ & $10 / 10$ & $10 / 10$ \\
\hline$(1-10) \times 10^{6}$ & $10 / 10$ & $4 / 10$ & $10 / 10$ & $10 / 10$ \\
\hline$(1-10) \times 10^{5}$ & $9 / 10$ & $4 / 10$ & $10 / 10$ & $10 / 10$ \\
\hline$(1-10) \times 10^{4}$ & $2 / 10$ & $3 / 10$ & $3 / 10$ & 9/10 \\
\hline$(1-10) \times 10^{3}$ & $0 / 10$ & $2 / 10$ & $1 / 10$ & $4 / 10$ \\
\hline$(1-10) \times 10^{2}$ & $0 / 10$ & $1 / 10$ & $0 / 10$ & $2 / 10$ \\
\hline$(1-10) \times 10$ & $0 / 10$ & $1 / 10$ & $0 / 10$ & $2 / 10$ \\
\hline$(1-10)$ & $0 / 10$ & $2 / 10$ & $0 / 10$ & $1 / 10$ \\
\hline $\begin{array}{l}\text { Analytical sensitivity } \\
\text { (diagnostic sensitivity) }\end{array}$ & $(1-10) \times 10^{5}(90 \%)$ & Non-determined & $(1-10) \times 10^{5}(100 \%)$ & $\begin{array}{l}(1-10) \times 10^{4}(90 \%) \\
(1-10) \times 10^{3}(40 \%)\end{array}$ \\
\hline
\end{tabular}

TABLE 5 - Proportion of positive results in the detection of leptospires from tissues infected experimentally with Copenhageni or Tropica serovars

\begin{tabular}{cccccc}
\hline \multirow{2}{*}{ Tissue } & \multicolumn{3}{c}{ Silver staining (modified Fontana) } & & \multirow{2}{*}{ Culture } \\
\cline { 2 - 5 } & Clarified imprints & Clarified smears & Non-clarified smears & & \\
\hline Kidney & $2 / 4$ & $1 / 4$ & $2 / 4$ & $2 / 4$ & $2 / 4$ \\
Liver & $2 / 4$ & $1 / 4$ & $3 / 4$ & $0 / 4$ & $1 / 4$ \\
Spleen & $1 / 4$ & $1 / 4$ & $2 / 4$ & $0 / 4$ & $2 / 4$ \\
Lung & $2 / 4$ & $4 / 4$ & $2 / 4$ & $2 / 4$ & $1 / 4$ \\
Heart & $3 / 4$ & $0 / 4$ & $1 / 4$ & $4 / 4$ & $3 / 4$ \\
\hline Total & $10 / 20$ & $7 / 20$ & $10 / 20$ & $4 / 20$ & $9 / 20$ \\
\hline
\end{tabular}

\section{DISCUSSION}

The standard stains for spirochetes have long been silver deposition methods, whose action depends on the reduction of silver salts, usually stabilized silver nitrate, by reducing surface sugars ${ }^{(7)}$.

The conventional protocol for Fontana technique is cumbersome and results in clouding of the smear due to excessive deposition of silver nitrate on other argyrophilic matter. Furthermore, development of artifacts due to lack of uniformity in staining is also observed ${ }^{(6)}$.

The key to success is to deal with the preparation as a photographic negative, washing out all reagents thoroughly before proceeding to the next step, and avoiding exposure to strong light or to extraneous reducing substances during the procedure. All traces of ethanol, methanol, or formalin used as a fixative must be thoroughly rinsed with water. The slide should be free of excess water at each step to avoid dilution of reagents. If these precautions are not observed, or if the leptospires are suspended and fixed in a medium that reduces the silver nitrate, the background will be dark instead of very pale yellow or colorless ${ }^{(2,7)}$.

The sensitivity of modified Fontana silver staining was compared with the isolation by culture and the dark ground microscopy using pure cultures of leptospires and human urine samples infected with leptospires. The isolation was the most sensitive assay for detecting leptospires, allowing the confirmation of results obtained by silver staining in those samples where there was a low concentration of leptospires. However, it was not possible to determine its sensitivity for urine specimens since leptospires are difficult to be cultured in artificial media. Additionally, the conditions of urine, namely the toxicity due to acid $\mathrm{pH}$ or due to the alkalinization process with a sodium hydroxide solution may have contributed to this result. The usefulness of differential centrifugation for the detection of leptospires in urine was demonstrated.

Despite the insensitivity and low specificity of dark-field microscopic examination of body fluids, it has been used as a diagnostic tool in some laboratories. The drawbacks of this test on clinical specimens have been that both false positive and false negative diagnosis can be easily made even by experienced professionals, insofar as artifacts such as serum proteins and cell fragments are mistakenly identified as leptospires in clinical samples. Although the organisms are presumably always present in the blood during the first week of contamination, they are rarely present in numbers sufficient to allow detection by direct microscopy. Moreover, leptospires are excreted in urine intermittently and the concentration of the organism may be too low. Therefore, the examination of clinical specimens using this 
method as the solely diagnostic procedure is not recommended in routine practice ${ }^{(8,14,18)}$.

Gangadhar and Rajasekhar evaluated the modified Fontana silver impregnation staining using several local isolates of leptospires and highlighted its effectiveness in terms of clear background of stained slides and demonstration of leptospire fine coils. Besides, all results were reproducible ${ }^{(6)}$.

We also evaluated this procedure for detecting leptospires from tissues experimentally infected with different leptospiral serovars. Golden Syrian hamsters were used because they are regarded as the most susceptible laboratory animals to the leptospiral illness and they reproduce with great fidelity the pathological clinical process of leptospirosis ${ }^{(10)}$, although the production of symptoms and the lethal activity are closely related with the virulence of the leptospiral strain $^{(13)}$.

In the present work, the use of trypsin on smear samples, in which the quantity of cellular material is poor in relation to the imprints, was maybe the cause of the lower sensitivity of this method in clarified smears.

The dark field microscopy for detecting leptospires from tissue suspension did not yield as good results as culture and silver staining, because the reading was difficult because of the presence of cell debris and blood remains in the samples.

When comparing the results from imprints and non-clarified smears for silver staining with those from culture, there was low correlation between the values. Compatible structures with leptospires were observed by silver staining, but isolation was not obtained by culture using the same sample. This could be due to the existence of some lithic elements present in the tissue suspension, as it is similarly observed when blood is cultured ${ }^{(7)}$, which affects the viability and multiplication of leptospires. The contamination with other bacterial groups given the nutritional enrichment of culture medium may also have influenced results. On the other hand, compatible structures with leptospires were not observed by silver impregnation but isolated by cultivation. This may have occurred due to the fact that the quantity of leptospires in samples was not enough to be visualized by silver impregnation, but it was enough to multiply and achieve its isolation.

The heart was the organ where leptospires were found most frequently through stained and clarified imprints, therefore it should be considered in order to establish the diagnosis of leptospirosis, mainly when the patient had an early death. Other organs such as kidney, spleen and liver are also commonly affected by leptospiras ${ }^{(2,11)}$. We also observed the invasiveness of leptospires in lungs at experimental level, since in recent leptospirosis outbreaks this organ is reported as one of the most affected, its damage being the main cause of death ${ }^{(4}$ 15,16).

When we applied the modified Fontana silver staining to noninoculated culture medium, non-infected urine and tissue samples from control animals, morphological and stainable structures compatible with leptospires were not observed. However, it is worth mentioning that analysis of tissue samples requires some experience in observing leptospiras stained by this procedure, inasmuch as there are artifacts that may lead to misinterpretations. Therefore, it is very important to observe the characteristic morphology in order to distinguish leptospira from other elements.

The silver staining technique was not specific for Leptospira and also stained various other bacterial or fungical forms. Characteristic morphology of leptospires (size and nature of the helix) is particularly helpful in distinguishing Leptospira from other microorganisms and artifacts, which are easily mistaken for leptospira ${ }^{(7)}$, though this method does not identify altered microorganisms or their antigenic products.

The modified Fontana silver staining procedure may have a potential as an aid to the diagnosis of leptospirosis in tissue samples (imprints) submitted to histopathology, and it does not require the preparation of paraffin-embedded formalin fixed tissues. This is the first evaluation of modified Fontana silver staining in urine and animal tissue samples.

This technique has proved to be advantageous. Clouding of the smear, development of artifacts or cracks of staining can be avoided. The efficacy of the slide reading is higher. The characteristic morphology of the organism is clearly discernible against a clear white background. Even small quantities can be easily detected. The reagents are stable and reusable for long periods. The major advantage is its simplicity, inasmuch as it can be performed in any laboratory with no special equipment, but it must be developed by professionals skilled in observing leptospires.

\section{CONCLUSIONS}

The modified Fontana silver staining could be an alternative tool for leptospirosis screening in poorly-resourced laboratories in developing countries, where this disease is a serious human and veterinary health problem. Furthermore, it has proved to be cost effective in comparison with molecular or immunohistochemical methods for the detection of leptospires, once it allows the direct use of imprints from tissues.

\section{RESUMO}

Introdução: O diagnóstico microbiológico da leptospirose inclui métodos bacteriológicos e sorológicos; os primeiros permitem a detecção direta de leptospiras e, à exceção do cultivo, são considerados como presuntivos, mas constituem ferramentas valiosas para o diagnóstico rápido, principalmente nos falecidos. Objetivo: Avaliar a coloração de prata Fontana modificada em amostras experimentalmente infectadas. Material e métodos: Urinas humanas e hamsters foram infectados experimentalmente com diferentes cepas de Leptospira interrogans sensu lato. Para a avaliação, foi utilizado meio de cultura líquido, culturas de leptospiras, urinas humanas experimentalmente 
infectadas e não infectadas, impressões clarificadas e não clarificadas e esfregaços de suspensões clarificadas e não clarificadas a partir de tecidos de hamsters infectados e não infectados para o experimento. A sensibilidade analíitica do ensaio foi comparada com a microscopia de campo escuro e de cultura. Outras estécies de bactérias e fungos também foram utilizadas. Resultados: A coloração de prata de Fontana modificada permitiu observar claramente e bem definida a estrutura belicoidal das leptospiras. Nas culturas destas e de urinas humanas infectadas, pôde-se observar até (1-10) $\times 10^{3}$ leptospiras $/$ ml, sensibilidade superior à da microscopia de campo escuro e inferior à da cultura. Os melhores resultados nos tecidos foram obtidos em impressões clarificadas e a partir de esfregaços de suspensões não clarificadas. Estruturas morfológicas e tingidas compatíveis com leptospiras não foram observadas nas amostras livres destas. Conclusão: Esse procedimento permitiu diferenciar a morfologia característica das leptospiras. É um procedimento simples, fácil de realizar e com reagentes estáveis pelo o que a sua aplicação é sugerida.

Unitermos: leptospira; impregnação por prata; leptospirosis; diagnóstico.

\section{REFERENCES}

1. ADLER, B.; DE LA PEÑA-MOCTEZUMA, A. Leptospira and leptospirosis. Vet Microbiol, v. 140, n. 3-4, p. 287-96, 2010.

2. BALLS, M.; FESTING, M. F. W.; FLECKNELL, P. A. The three Rs: developments in laboratory animal science. London: Laboratory Animals Ltd, 2001.

3. CLOSE, B. et al. Recommendations for euthanasia of experimental animals. London: Laboratory Animals Ltd, 1996/1997.

4. DOLHNIKOFF, M. et al. Pathology and pathophysiology of pulmonary manifestations in leptospirosis. Braz J Infect Dis, v. 11, n. 1, p. 142-8, 2007.

5. FAINE, S. et al. Leptospira and leptospirosis. Melbourne: Medi Sci, 1999.

6. GANGADHAR, N.; RAJASEKJAR, M. A modified silver impregnation staining for leptospiras. Indian Vet J, v. 75, p. 349-51, 1998.

7. HARTSKEERL, R. A. et al. International course on laboratory methods for the diagnosis of leptospirosis. Havana: Palcograf, 2008.

8. HERNÁNDEZ-RODRÍGUEZ, P. et al. A comparison between polymerase chain reaction (PCR) and traditional techniques for the diagnosis of leptospirosis in bovines. J Microbiol Methods, v. 84, n. 1, p. 1-7, 2011.

9. HOTEZ, P. J. et al. The neglected tropical diseases of Latin America and the Caribbean: a review of disease burden and distribution and a roadmap for control and elimination. PLoS Negl Trop Dis, v. 2, n. 9, p. e300, 2008.

10. INFANTE, J. et al. Los biomodelos aplicados al desarrollo de vacunas y sueros en el Instituto Finlay. Rev Hisp Anim, v. 3, p. 30-40, 1998.
11. LEON, A. et al. Identification of pathogenic Leptospira strains in tissues of a premature foal by use of polymerase chain reaction analysis. J Vet Diagn Invest, v. 18, n. 2, p. 218-21, 2006.

12. MCBRIDE, A. J. et al. Leptospirosis. Curr Opin Infect Dis, v. 18, n. 5 , p. 376-86, 2005 .

13. OLIVA, R. et al. Pathologic-clinical characterization of leptospirosis in a golden Syrian hamster model. Arch Med Res, v. 25, n. 2, p. 165-70, 1994.

14. RAO, P. S.; SHASHIBHUSHAN, P.; SHIVANANDA, P. G. Comparison of darkground microscopy with serological tests in the diagnosis of leptospirosis with hepatorenal involvement. A preliminary study Indian. J Pathol Microbiol, v. 41, n. 4, p. 427-9, 1998.

15. SEIJ0, A. et al. Lethal leptospiral pulmonary hemorrhage. An emerging disease in Buenos Aires, Argentina. Emerg Infect Dis, v. 8, n. 9, p. 1003-4, 2002.

16. VIJAYACHARI, P. et al.Leptospira interrogans serovar Valbuzzi: a cause of severe pulmonary haemorrhages in the Andaman Islands.J Med Microbiol, v. 52, n. 10, p. 913-8, 2003.

17. VIJAYACHARI, P.; SUGUNAN, A. P.; SHRIDAM, A. N. Leptospirosis: an emerging global public health problem.J Biosci, v. 33, n. 4, p. 557-69, 2008.

18. VIJAYACHARI, P. et al. Evaluation of darkground microscopy as a rapid diagnostic procedure in leptospirosis. Indian J Med Res, v. 114, p. 54-8, 2001.

19. WHO-ILS. Human leptospirosis: guidance for diagnosis, surveillance and control. Rio de Janeiro: Panamerican Centre of Aftosa Fever- VP/PAHO/WHO, 2008 .

\section{MAILING ADDRESS}

\section{Islay Rodríguez}

Tropical Medicine Institute Pedro Kourí; Autopista Novia del Mediodía km 6 1/2, La Lisa; P0 Box 601, Marianao 13; Havana - Cuba; e-mail: islay@ipk.sld.cu 